\title{
The Effects of Dopamine Infusion on Regional Blood Flow in Newborn Lambs
}

\author{
TIMOTHY F. FELTES, THOMAS N. HANSEN, CHRISTOPHER G. MARTIN, \\ ADRIAN L. LEBLANC, SHERILYN SMITH, AND MARK E. GIESLER
}

Department of Pediatrics, Baylor College of Medicine, Houston, Texas 77030

\begin{abstract}
The purpose of this project was to investigate the effects of high rates of dopamine infusion on cardiac output and regional blood flow in the lamb. We studied eight unanesthetized newborn lambs (mean age $7 \pm 2$ days) during a 15-min baseline period and while infusing dopamine at 5-, 20-, 80-, and $160 \mu \mathrm{g} / \mathrm{kg} / \mathrm{min}$. We measured cardiac output and mean aortic, pulmonary arterial and left atrial pressures, and organ blood flow using radionuclidelabeled microspheres at each rate of dopamine infusion. Cardiac output increased significantly with increasing rates of infusion up to $80 \mu \mathrm{g} / \mathrm{kg} / \mathrm{min}$ but decreased at $160 \mu \mathrm{g} / \mathrm{kg} /$ min. Aortic, pulmonary arterial, and left atrial pressures increased at rates of infusion above $5 \mu \mathrm{g} / \mathrm{kg} / \mathrm{min}$. Blood flow to all organs was unchanged at the $5 \mu \mathrm{g} / \mathrm{kg} / \mathrm{min}$ rate of infusion of dopamine while blood flow to the brain and heart increased at the $80 \mu \mathrm{g} / \mathrm{kg} / \mathrm{min}$ rate of infusion and blood flow to the gut and kidney decreased. We conclude that dopamine is an effective inotropic agent in the newborn lamb but that an inotropic:afterload mismatch exists at high infusion rates. Despite an increase in cardiac output at low rates of infusion, dopamine did not selectively vasodilate the vascular bed of any organs tested. Furthermore, at high rates of infusion dopamine actually impaired blood flow to the gut and kidney. (Pediatr Res 21: 131-136, 1987)
\end{abstract}

Dopamine remains an extensively used catecholamine in the management of shock in critically ill infants and children (1). We recently studied the effects of dopamine on hemodynamics in 2- to 3-wk-old lambs and found it to be an effective inotropic agent (2). However, inherent properties of neonatal myocardium may render it relatively unresponsive to the inotropic actions of dopamine and the same effects may not occur in the younger lamb. In the clinical setting, myocardial immaturity may prompt the use of rates of infusion of dopamine in excess of those currently recommended (1). The effects of high rates of infusion on regional blood flow in the newborn are unknown.

The purpose of our study was to investigate the effects of dopamine on regional blood flow in newborn lambs over a wide range of infusion rates. We hypothesized that in the newborn lamb dopamine would not increase cardiac output at conventionally used rates of infusion but might at higher rates. At these higher rates, however, we anticipated that the $\alpha$-adrenergic effect of dopamine would compromise blood flow to vital organs.

\section{MATERIALS AND METHODS}

Surgical preparations. We operated on eight lambs using halothane and nitrous oxide anesthesia delivered by a piston type

Received May 8. 1986: accepted September 15, 1986.

Address correspondence to Thomas N. Hansen. M.D.. Department of Pediatrics. Baylor Coliege of Medicine. One Baylor Plaza. Houston. TX 77030. ventilator. From a left hindlimb cutdown we inserted polyvinyl catheters into a peripheral artery and vein and advanced them into the descending aorta and inferior vena cava, respectively. We also inserted a 3.5 Fr thermistor wire (Edwards Laboratories, Inc., Irvine, $\mathrm{CA}$ ) into a peripheral artery by separate hindlimb cutdown and advanced it into the descending aorta. Finally, we placed a polyvinyl catheter in a forelimb artery and advanced it into the ascending aorta.

Next, through a left thoracotomy, we placed polyvinyl catheters directly into the left atrium and pulmonary artery and isolated and ligated the ductal remnant. We tunneled the catheters to the left chest and covered them with a vinyl pouch sewn to the skin. Once ambulatory all lambs recovered with their ewes for at least $72 \mathrm{~h}$ before participating in the study.

Experimental protocol. We studied the lambs as they rested prone in a sling that did not interfere with respiratory movements. Throughout the experiment we measured mean and phasic pulmonary arterial, left atrial and aortic pressures, and heart rate using Statham P23Db strain gauge manometers (Statham Instruments, Hato Rey, Puerto Rico) and a Grass 7D 8channel amplifier recorder (Grass Instruments, Quincy, MA). At each rate of infusion we measured cardiac output in triplicate by the thermodilution technique. We injected iced saline through the catheter in the left atrium, measured the temperature change in the descending aorta, and calculated cardiac output using a Gould Statham SP1425 computer. In addition, we obtained samples of arterial blood at each rate of dopamine infusion for determination of hematocrit and for measurement of arterial blood gas tensions using a Radiometer Blood Gas Analyzer (PM27, Radiometer Corp., Copenhagen, Denmark) set at $39.5^{\circ}$ C. Finally, we calculated pulmonary vascular resistance as the difference between mean pulmonary arterial and left atrial pressures divided by the cardiac output. We studied the lambs during a baseline period and while infusing dopamine (American Critical Care, McGraw Park, IL) through a central venous catheter at rates of 5-, 20,- 80-, and $160 \mu \mathrm{g} / \mathrm{kg} / \mathrm{min}$. We allowed the lambs to stabilize for at least $15 \mathrm{~min}$ at each rate of dopamine infusion before obtaining any measurements.

At each rate of dopamine infusion, we determined regional blood flow by injecting approximately $1.0 \times 10^{6}$ microspheres (15 $\mu \mathrm{m}$ in diameter) labeled with one of five radionucleotides (New England Nuclear $\mathrm{Sc}^{46}, \mathrm{Co}^{57}, \mathrm{Nb}^{95}, \mathrm{Ru}^{101}, \mathrm{Sn}^{113}$ ) directly into the left atrium over $15 \mathrm{~s}$ and then flushing the left atrial catheter with $10 \mathrm{ml}$ of sterile normal saline. We obtained blood samples from upper and lower body arterial catheters in preweighed glass syringes at a constant withdrawal rate of $3.9 \mathrm{ml} /$ min beginning just before microsphere injection and continuing for $45 \mathrm{~s}$ after the injection was completed.

At the completion of each study, we killed the lamb with an intravenous injection of pentobarbital and $\mathrm{KCl}$ and removed the brain, heart, gut from the pylorus to the distal colon, liver, and kidneys. We weighed and homogenized the organs with $10 \%$ formalin solution and determined the radioactivity of the tissue 
homogenate and reference blood samples using a sodium iodide scintillation detector and a multichannel pulse height analyzer. Finally we calculated tissue blood flow using the surrogate organ method of Rudolph and Heymann (3) where $\left(F_{u}\right)$ is flow to the unknown organ, $\left(\mathrm{C}_{\mathrm{u}}\right)$ are the counts per minute detected in the unknown organ, and $\left(F_{r}\right)$ and $\left(C_{r}\right)$ are the flow and counts per minute in the arterial reference sample: $\left[\mathrm{F}_{\mathrm{u}}=\mathrm{C}_{\mathrm{u}}\left(\mathrm{F}_{\mathrm{r}} / \mathrm{C}_{\mathrm{r}}\right)\right](4,5)$.

\section{STATISTICS}

All data are reported as the mean value \pm 1 SEM. A two-way analysis of variance with a student Newman-Kuel's test was used to assess differences between incremental rates of dopamine infusion. We regarded a $p$ value of $<0.05$ as significant (6). $\mathrm{pH}$ values were converted to the $-\log \left[\mathrm{H}^{+}\right]$before analysis.

\section{RESULTS}

Our lambs ranged in age from 5 to 12 days $(7 \pm 2)$ and weight from 3.4 to $9.0 \mathrm{~kg}(5.5 \pm 1.8)$. Hematocrit and $\mathrm{P}_{\mathrm{a}} \mathrm{O}_{2}$ did not change during dopamine infusion (Table 1). $\mathrm{P}_{\mathrm{a}} \mathrm{CO}_{2}$ increased slightly at the 20 and $80 \mu \mathrm{g} / \mathrm{kg} / \mathrm{min}$ rates of dopamine infusion, but returned to baseline values at the highest rate of infusion while $\mathrm{pH}$ decreased progressively throughout the experiment.

Hemodynamics. Cardiac output during the baseline period was $346 \pm 22 \mu \mathrm{g} / \mathrm{kg} / \mathrm{min}$. It increased significantly at the $20 \mu \mathrm{g} /$ $\mathrm{kg} / \mathrm{min}$ rate of infusion, did not change at $80 \mu \mathrm{g} / \mathrm{kg} / \mathrm{min}$, and then decreased at the $160 \mu \mathrm{g} / \mathrm{kg} / \mathrm{min}$ rate of infusion (Fig. 1).

Systemic and pulmonary arterial pressures increased significantly at infusion rates of 20 and $80 \mu \mathrm{g} / \mathrm{kg} / \mathrm{min}$, respectively. Despite the fall in cardiac output, systemic arterial pressure continued to increase at the $160 \mu \mathrm{g} / \mathrm{kg} / \mathrm{min}$ rate of infusion (peaking $79 \%$ over baseline) (Fig. 2).

Left atrial pressure did not change at low and intermediate rates of infusion but increased significantly at the $160 \mu \mathrm{g} / \mathrm{kg} /$ min rate of infusion (Fig. 2).

Systemic vascular resistance did not change at the 5 and 20 $\mu \mathrm{g} / \mathrm{kg} / \mathrm{min}$ rates of infusion despite the increase in cardiac output but did increase significantly at the 80 and $160 \mu \mathrm{g} / \mathrm{kg} / \mathrm{min}$ rates of infusion (Fig. 3). At the $160 \mu \mathrm{g} / \mathrm{kg} / \mathrm{min}$ rate of infusion, sytemic vascular resistance was $67 \%$ greater than baseline.

In contrast, pulmonary vascular resistance was not appreciably altered by dopamine infusion (Fig. 3) despite the increase in both cardiac output and left atrial pressure. The combined effects of dopamine on the systemic and pulmonary vascular resistances resulted in a decrease in the pulmonary to systemic vascular resistance ratio at high rates of infusion.

Heart rate increased from $170 \pm 20$ to $225 \pm 16 \mathrm{bpm}$ between the 80 and $160 \mu \mathrm{g} / \mathrm{kg} / \mathrm{min}$ rates of dopamine infusion.

Tissue blood flow. Brain blood flow did not change at the 5 and $20 \mu \mathrm{g} / \mathrm{kg} / \mathrm{min}$ rates of infusion but increased at the $80 \mu \mathrm{g} /$ $\mathrm{kg} / \mathrm{min}$ rate of infusion, and peaked $25 \%$ over baseline (with the peak in aortic pressure) at the $160 \mu \mathrm{g} / \mathrm{kg} / \mathrm{min}$ rate of infusion (Table 2) (Fig. 4). Since cardiac output decreased at this rate of infusion the relative proportion of cardiac output distributed to the brain increased $40 \%$ (Table 3 ).

Myocardial blood flow increased slightly at the $20 \mu \mathrm{g} / \mathrm{kg} / \mathrm{min}$ rate of infusion but its percentage of total cardiac output remained unchanged (Fig. 4). At the 80 and $160 \mu \mathrm{g} / \mathrm{kg} / \mathrm{min}$ rates of infusion, however, myocardial flow increased dramatically, tripling its proportion of the total cardiac output.

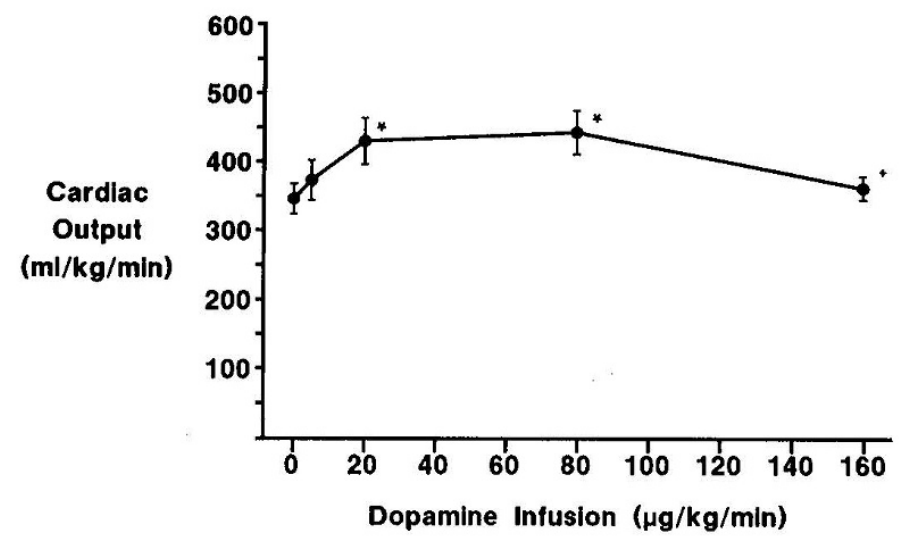

Fig. 1. Effects of dopamine infusion on cardiac output. Infusion of dopamine at $20 \mu \mathrm{g} / \mathrm{kg} / \mathrm{min}$ increased cardiac output significantly compared to baseline. Cardiac output remained increased at $80 \mu \mathrm{g} / \mathrm{kg} / \mathrm{min}$ and then decreased at $160 \mu \mathrm{g} / \mathrm{kg} / \mathrm{min}{ }^{*}$ different from baseline $(p<$ $0.05)$; $\dagger$ different from $80 \mu \mathrm{g} / \mathrm{kg} / \mathrm{min}(p<0.05)$.

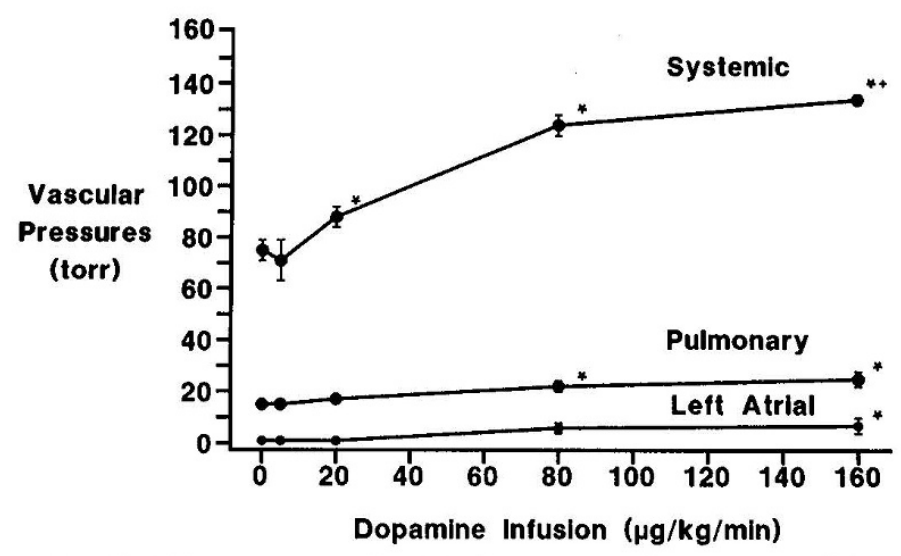

Fig. 2. Effects of dopamine infusion on vascular pressures. Mean systemic arterial pressure increased at both the 20 and $160 \mu \mathrm{g} / \mathrm{kg} / \mathrm{min}$ rates of infusion. Mean pulmonary arterial pressure increased at the 80 $\mu \mathrm{g} / \mathrm{kg} / \mathrm{min}$ rate of infusion while mean left atrial pressure increased only at $160 \mu \mathrm{g} / \mathrm{kg} / \mathrm{min}$. * different from baseline $(p<0.05)$; $\uparrow$ different from $80 \mu \mathrm{g} / \mathrm{kg} / \mathrm{min}(p<0.05)$.

Table 1. Hemodynamic effects of dopamine infusion

\begin{tabular}{|c|c|c|c|c|c|c|c|c|c|c|c|}
\hline $\begin{array}{c}\text { Dopamine } \\
(\mu \mathrm{g} / \mathrm{kg} / \mathrm{min})\end{array}$ & $\begin{array}{c}\text { Cardiac } \\
\text { output }(\mathrm{ml} / \\
\mathrm{kg} / \mathrm{min})\end{array}$ & $\begin{array}{c}\text { Mean } \\
\text { aortic } \\
\text { pressure } \\
\text { (torr) }\end{array}$ & $\begin{array}{c}\text { Mean } \\
\text { pulmonary } \\
\text { pressure } \\
\text { (torr) }\end{array}$ & $\begin{array}{c}\text { Mean left } \\
\text { atrial } \\
\text { pressure } \\
\text { (torr) }\end{array}$ & $\begin{array}{c}\text { Systemic } \\
\text { vascular } \\
\text { resistance } \\
\text { (torr } / \mathrm{liter} / \\
\mathrm{min} / \mathrm{kg} \text { ) }\end{array}$ & $\begin{array}{l}\text { Pulmonary } \\
\text { vascular } \\
\text { resistance } \\
\text { (torr } / \mathrm{liter} / \\
\mathrm{min} / \mathrm{kg} \text { ) }\end{array}$ & $\begin{array}{c}\text { Pulmonary } \\
\div \\
\text { systemic } \\
\text { vascular } \\
\text { resistance } \\
\end{array}$ & $\begin{array}{c}\text { Heart rate } \\
\text { (beats/min) }\end{array}$ & $\mathrm{pH}$ & $\begin{array}{c}\mathrm{p}_{\mathrm{a}} \mathrm{O}_{2} \\
\text { (torr) }\end{array}$ & $\begin{array}{l}\mathrm{p}_{\mathrm{a}} \mathrm{CO}_{2} \\
\text { (torr) }\end{array}$ \\
\hline 0 & $346 \pm 21$ & $75 \pm 4$ & $15 \pm 1$ & $1 \pm 1$ & $225 \pm 24$ & $42 \pm 4$ & $0.19 \pm 0.01$ & $161 \pm 13$ & $7.45 \pm 0.01$ & $80 \pm 3$ & $46 \pm 1$ \\
\hline 5 & $373 \pm 29$ & $71 \pm 3$ & $15 \pm 1$ & $0 \pm 1$ & $198 \pm 18$ & $42 \pm 5$ & $0.21 \pm 0.01$ & $161 \pm 13$ & $7.42 \pm 0.02 *$ & $80 \pm 2$ & $48 \pm 2$ \\
\hline 20 & $430 \pm 34^{*}$ & $88 \pm 4^{*}$ & $17 \pm 1$ & $1 \pm 1$ & $209 \pm 11$ & $41 \pm 5$ & $0.12 \pm 0.02$ & $162 \pm 15$ & $7.40 \pm 0.01^{*}$ & $78 \pm 2$ & $51 \pm 2^{*}$ \\
\hline 80 & $443 \pm 32 *$ & $124 \pm 4^{*}$ & $22 \pm 2^{*}$ & $6 \pm 2$ & $288 \pm 17^{*}$ & $39 \pm 4$ & $0.13 \pm 0.01 *$ & $170 \pm 20$ & $7.36 \pm 0.02^{*}$ & $77 \pm 2$ & $51 \pm 1^{*}$ \\
\hline 160 & $362 \pm 17 \dagger$ & $134 \pm 2^{*}, \dagger$ & $25 \pm 2^{*}$ & $7 \pm 3^{*}$ & $375 \pm 17^{*}, \uparrow$ & $47 \pm 5$ & $0.12 \pm 0.01 *$ & $225 \pm 16^{*}, \dagger$ & $7.33 \pm 0.02 *, \uparrow$ & $76 \pm 2$ & $48 \pm 2$ \\
\hline
\end{tabular}

$*$ Different from baseline $(p<0.05)$.

$\uparrow$ Different from $80 \mu \mathrm{g} / \mathrm{kg} / \mathrm{min}(p<0.05)$. 


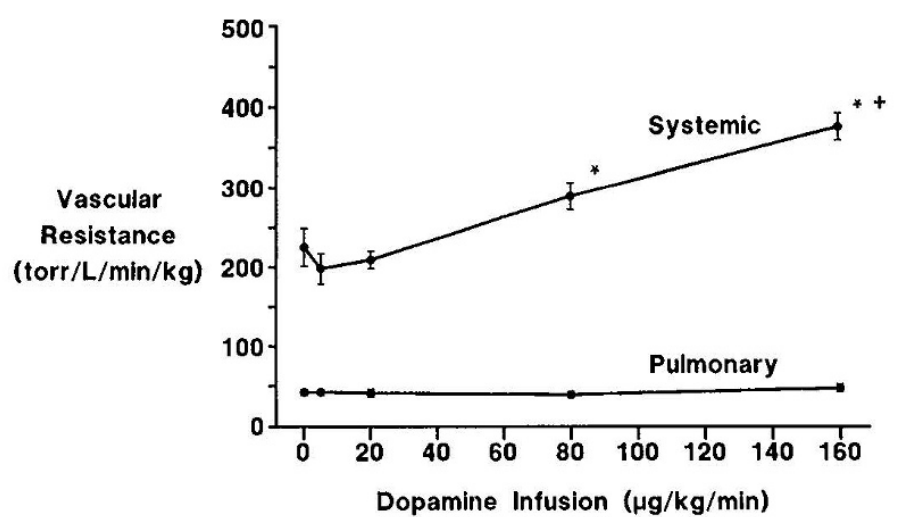

Fig. 3. Effects of dopamine infusion on vascular resistances. Systemic vascular resistance increased significantly at both the 80 and $160 \mu \mathrm{g} / \mathrm{kg} /$ min rates of infusion. Pulmonary vascular resistance was not affected by dopamine infusion. * different from baseline $(p<0.05) ; \uparrow$ different from $80 \mu \mathrm{g} / \mathrm{kg} / \mathrm{min}(p<0.05)$.
Gut blood flow was not changed at the 5 and $20 \mu \mathrm{g} / \mathrm{kg} / \mathrm{min}$ but decreased $28 \%$ from baseline at the $80 \mu \mathrm{g} / \mathrm{kg} / \mathrm{min}$ rates of infusion and an additional $12 \%$ at the $160 \mu \mathrm{g} / \mathrm{kg} / \mathrm{min}$ rate of infusion (Fig. 4). Gut flow represented only $11.7 \%$ of the total cardiac output at the high rate of infusion compared to the baseline of $17.9 \%$.

Baseline hepatic arterial blood flow decreased $39 \%$ at the 160 $\mu \mathrm{g} / \mathrm{kg} / \mathrm{min}$ rate of infusion (Fig. 4). This change was not significant.

Renal blood flow decreased $24 \%$ from baseline at the $80 \mu \mathrm{g} /$ $\mathrm{kg} / \mathrm{min}$ and an additional $21 \%$ at the $160 \mu \mathrm{g} / \mathrm{kg} / \mathrm{min}$ rates of infusion (Fig. 4). Renal blood flow represented only $6.16 \%$ of the total cardiac output at the highest rate of infusion in contrast to a baseline value of $11.29 \%$ ).

\section{DISCUSSION}

Dopamine, an endogenous catecholamine, is frequently used to support the circulation of the critically ill infant (7). Its positive inotropic effect results from both direct and indirect $\beta_{1}$ adreno-

Table 2. Tissue blood flow $(\mathrm{ml} / \mathrm{g} / \mathrm{min})$

\begin{tabular}{cccccc}
\hline $\begin{array}{c}\text { Dopamine } \\
(\mu \mathrm{g} / \mathrm{kg} / \mathrm{min})\end{array}$ & Brain & Heart & Gut & Liver & Kidney \\
\hline 0 & $1.48 \pm 0.14$ & $1.94 \pm 0.20$ & $2.52 \pm 0.33$ & $0.23 \pm 0.04$ & $5.59 \pm 0.28$ \\
5 & $1.48 \pm 0.15$ & $1.83 \pm 0.14$ & $2.05 \pm 0.25$ & $0.21 \pm 0.05$ & $4.95 \pm 0.23$ \\
20 & $1.63 \pm 0.14$ & $2.36 \pm 0.21$ & $2.55 \pm 0.35$ & $0.20 \pm 0.05$ & $6.16 \pm 0.30$ \\
80 & $1.82 \pm 0.17^{*}$ & $5.27 \pm 0.74^{*}$ & $1.82 \pm 0.19^{*}$ & $0.20 \pm 0.06$ & $4.22 \pm 0.14^{*}$ \\
160 & $1.85 \pm 0.14^{*}$ & $6.61 \pm 0.95^{*}, \dagger$ & $1.51 \pm 0.19^{*}$ & $0.14 \pm 0.03$ & $3.07 \pm 0.22^{*}, \dagger$ \\
\hline
\end{tabular}

* Different from baseline $(p<0.05)$.

$\dagger$ Different from $80 \mu \mathrm{g} / \mathrm{kg} / \mathrm{min}(p<0.05)$.
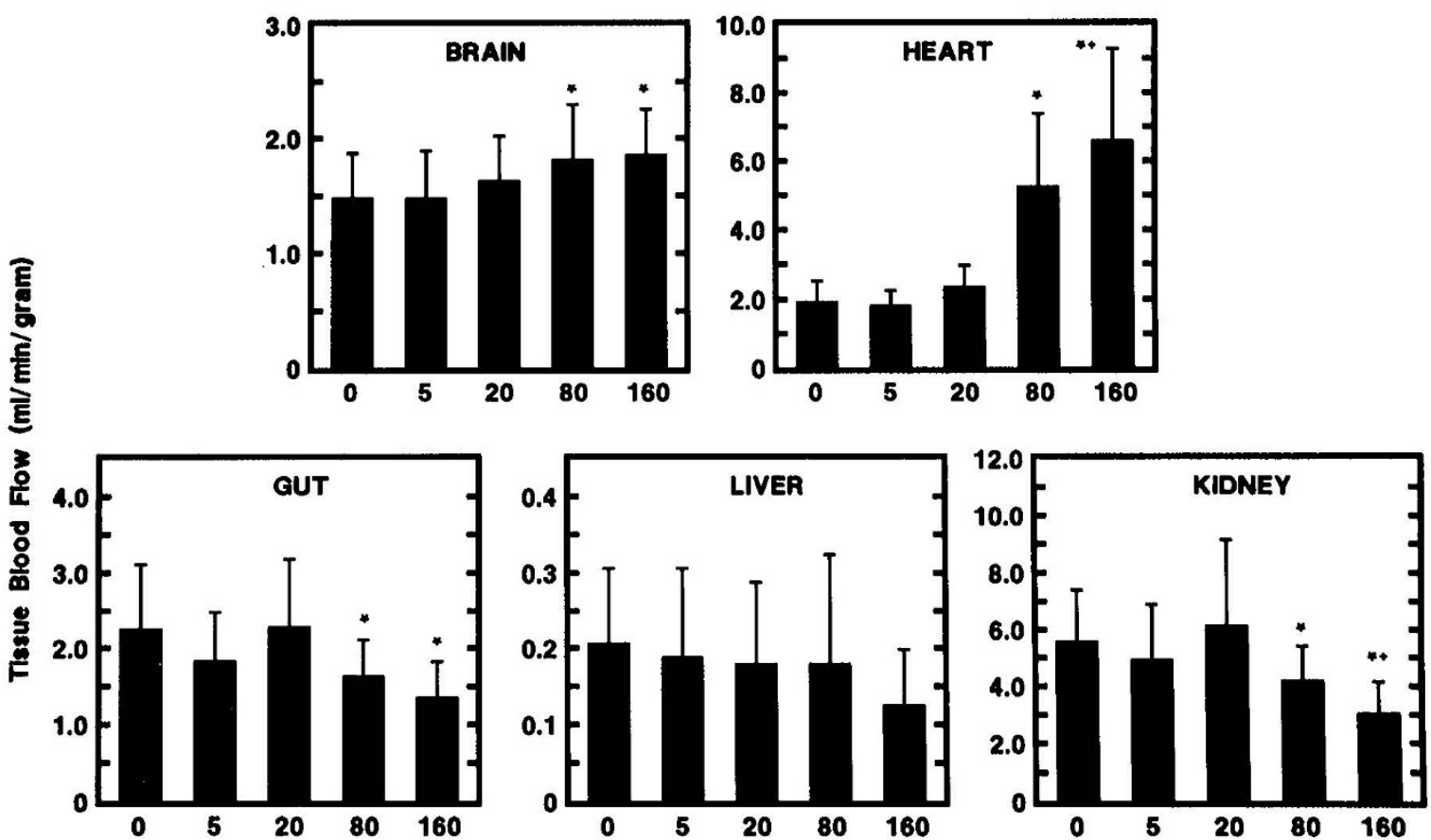

Dopamine Dose $(\mu \mathrm{g} / \mathbf{k g} / \mathrm{min})$

Fig. 4. Effects of dopamine infusion on tissue blood flow. Myocardial blood flow increased at both the 80 and $160 \mu \mathrm{g} / \mathrm{kg} / \mathrm{min}$ rates of infusion while brain blood flow increased only at $80 \mu \mathrm{g} / \mathrm{kg} / \mathrm{min}$. Blood flow to the kidneys decreased at both the 80 and $160 \mu \mathrm{g} / \mathrm{kg} / \mathrm{min}$ rates of infusion while blood flow to the gut decreased only at $80 \mu \mathrm{g} / \mathrm{kg} / \mathrm{min}$. Arterial blood flow to the liver was not altered by dopamine infusion. * different from baseline $(p<0.05)$; $\uparrow$ different from $80 \mu \mathrm{g} / \mathrm{kg} / \mathrm{min}(p<0.05)$. 
Table 3. Tissue blood flow as \% total cardiac output

\begin{tabular}{cccccc}
\hline $\begin{array}{c}\text { Dopamine } \\
(\mu \mathrm{g} / \mathrm{kg} / \mathrm{min})\end{array}$ & Brain & Heart & Gut & Liver & Kidney \\
\hline 0 & $3.91 \pm 0.48$ & $4.06 \pm 0.18$ & $17.90 \pm 1.84$ & $1.50 \pm 0.24$ & $11.29 \pm 0.83$ \\
5 & $4.13 \pm 0.53$ & $3.92 \pm 0.30$ & $14.94 \pm 1.89$ & $1.38 \pm 0.24$ & $9.69 \pm 0.66$ \\
20 & $3.92 \pm 0.64$ & $4.26 \pm 0.46$ & $14.73 \pm 1.23$ & $1.08 \pm 0.17$ & $10.00 \pm 0.86$ \\
80 & $4.56 \pm 0.60$ & $9.85 \pm 1.16^{*}$ & $11.94 \pm 1.36^{*}$ & $1.16 \pm 0.32$ & $7.74 \pm 0.70^{*}$ \\
160 & $5.50 \pm 0.72^{*}, \dagger$ & $14.45 \pm 1.78^{*}, \dagger$ & $11.70 \pm 1.60^{*}$ & $0.94 \pm 0.18$ & $6.16 \pm 0.94^{*}, \dagger$ \\
\hline
\end{tabular}

* Different from baseline $(p<0.05)$.

$\uparrow$ Different from $80 \mu \mathrm{g} / \mathrm{kg} / \mathrm{min}(p<0.05)$.

receptor activation in the myocardium (8). Dopamine directly stimulates $\beta_{1}$ receptors on the surface of the myocyte and increases intracellular cyclic AMP (9). As a result, an increased number of membrane slow calcium channels are recruited during the action potential of the myocyte resulting in an increase in intracellular calcium $(9,10)$. The increase in intracellular calcium increases the number of actin-myosin cross bridges resulting in enhanced inotropy (9).

Dopamine indirectly stimulates the myocardial $\beta_{1}$ receptor by releasing norepinephrine from the presynaptic terminals of intramyocardial sympathetic fibers (11). Once released into the synaptic junction, norepinephrine activates postsynaptic $\beta$ receptors on the myocyte resulting in the cascade of actin-myosin interaction mentioned above. Finally, dopamine may delay the breakdown and reuptake of norepinephrine from the synaptic junction of the myocardium and thus prolong the inotropic effects of the neurotransmitter $(8,12-14)$. The inotropic effect of dopamine, therefore, is dependent on 1) the integrity of the adrenergic receptor, 2) the extent of sympathetic innervation of the myocardium, 3) availability of norepinephrine stores in the presynaptic terminal, and 4) the number of contractile elements of the myocyte.

We found, as have others $(2,15)$, that the inotropic response to dopamine infusion was blunted in the very young animal suggesting that one or more of these factors may be deficient. Cheng et al. (16) have shown that the concentration of the $\beta_{1}$ receptors in the newborn heart is comparable to that of the adult and, unlike vascular adrenoreceptors, the myocardial $\beta_{1}$ receptor appears to be fully mature at birth (17). Therefore, we would expect the direct actions of dopamine to be little affected by maturity.

On the other hand, norepinephrine stores are reduced in the hearts of newborn lambs and the sympathetic innervation of the newborn myocardium is incomplete (17). As a result norepinephrine, which is released from sympathetic fibers in the heart by the direct action of dopamine, would have limited bioavailability to the postsynaptic $\beta_{1}$ receptor until postnatal completion of myocardial innervation. As a result, the indirect actions of dopamine on the myocardium might very well be affected by maturation.

Finally, the neonatal myocardial inotropic reserve is limited by the comparatively high proportion of noncontractile to contractile elements in the neonatal myocardium compared to the adult myocardium (17). These noncontractile elements, made up of intracellular organelles and surface membranes, result in a limited compliance of the newborn ventricle and a disproportionately low amount of contractile protein.

Although the response was blunted in comparison to that of the older lambs studied in our laboratory, dopamine, at rates of infusion used clinically, increased the cardiac output of our young lambs (2). This finding differs from that of several previous reports in comparably aged lambs where dopamine did not increase cardiac output at doses up to $360 \mu \mathrm{g} / \mathrm{kg} / \mathrm{min}(18,19)$. In these previous studies, however, arrhythmias frequently occurred at higher doses of dopamine which may have prevented cardiac output from increasing. Arrhythmias were infrequently encountered in our study. Cardiac output is a function of heart rate, preload, afterload, and myocardial contractility. At the 20 $\mu \mathrm{g} / \mathrm{kg} / \mathrm{min}$ rate of infusion, cardiac output increased in all of our lambs. Because heart rate, preload, and vascular resistance were unchanged at this infusion rate we assume that contractility increased.

Cardiac output decreased at very high rates of infusion of dopamine, a phenomenon not seen in our older lambs. We believe that this occurred not because of depleted inotropic reserve, but rather as the result of an inotropic:afterload imbalance. Vapaavouri et al. (20), studying fetal, newborn, and older lambs found a disparate maturation of vascular adrenoreceptors. The vasoconstriction mediating $\alpha$ receptors appeared to be fully developed by 120 days gestation (full gestation $=150$ days) while peripheral vasodilating $\beta_{2}$ receptors required postnatal maturation. The combination of limited inotropic reserve coupled with a predominant systemic vasoconstrictive response to high infusion rates of dopamine as evidenced by increased aortic pressure and systemic vascular resistance, led to an inotropic:afterload mismatch resulting in the fall in cardiac output. It was interesting that Downing et al. (21) using an in situ model of the newborn lamb heart, reported a decrease in stroke volume as systemic pressure (afterload) was increased within the range of aortic pressures that we observed in our study.

At low to moderate rates of infusion all of the lambs developed a mild respiratory acidosis that was most likely the result of dopamine-induced chemosensory inhibition (22). At higher rates of infusion the lambs also developed a metabolic acidosis suggesting that some degree of tissue ischemia was occurring. While Fisher $(23)$ has shown that severe metabolic acidosis $(\mathrm{pH}<7.11)$ may decrease cardiac output in newborn lambs it is unlikely that the small decrease in $\mathrm{pH}$ observed in our lambs could have accounted for the decrease in cardiac output seen at the $160 \mu \mathrm{g} /$ $\mathrm{kg} / \mathrm{min}$ rate of dopamine infusion. In Fisher's study there was no effect of acidosis on cardiac output at an arterial $\mathrm{pH}>7.30$ (Fisher DJ, personal communication) and in our previous study in older lambs, cardiac output increased at all rates of dopamine infusion despite a similar mild mixed acidosis (2). Finally, in previous studies where mild metabolic acidosis was induced by prolonged hypoxia (24), mixed acidosis was induced by hypoxia plus $\mathrm{CO}_{2}$ rebreathing (25), or pure respiratory acidosis was induced by $\mathrm{CO}_{2}$ rebreathing (26) cardiac output always increased.

Although we observed an increase in heart rate at high rates of dopamine infusion, it is unlikely that this impaired ventricular filling enough to account for the rise in left atrial pressure. Fisher and Gross (27) have shown that pacing the newborn lamb heart at rates up to $300 \mathrm{bpm}$ caused no significant increase in left atrial or left ventricular end diastolic pressure. It is more likely that the left atrial hypertension seen at high rates of infusion resulted from the markedly elevated systemic vascular resistance (i.e. afterload) thereby decreasing left ventricular stroke volume and impeding ventricular ejection.

Previous reports have demonstrated that increases in pulmonary blood flow and left atrial pressure decrease pulmonary vascular resistance (28). Both an increase in cardiac output and left atrial pressure occurred in our lambs with increasing rates of 
infusion of dopamine, yet pulmonary vascular resistance was not affected. This lack of passive dilatation with increased blood flow and increasing distending pressure suggests that dopamine increased the resting tone of the pulmonary vascular bed.

We found no change in blood flow to any organ at rates of dopamine infusion less than $80 \mu \mathrm{g} / \mathrm{kg} / \mathrm{min}$. At the 80 and 160 $\mu \mathrm{g} / \mathrm{kg} / \mathrm{min}$ rates of infusion, brain and myocardial flow increased while gut and renal flow decreased. Infusion of dopamine has been shown to result in vasodilatation in the cerebral, coronary, hepatosplanchnic, and renal vascular beds in either in vivo or in vitro preparations (29-39) presumably by stimulation of specific "dopaminergic" receptors $(8,29)$. Our regional flow data suggest that this vasodilating response to dopamine is not present in the 1 -wk-old lamb. These observations support the theory of Gootman et al. $(40,41)$ and others (42) that in the postnatal period, vascular autonomic receptors mature at different rates $(40)$, with the $\alpha$ adrenergic receptor being mature at birth, but the "dopaminergic" receptor requiring significant postnatal development.

The fact that blood flow to the gut and kidneys decreased while cardiac output increased at the $80 \mu \mathrm{g} / \mathrm{kg} / \mathrm{min}$ infusion rate of dopamine suggests that active vasoconstriction occurred in these organ beds. It is likely that the increase in organ vascular resistance was mediated by $\alpha$ adrenergic stimulation (35). Dopamine has been shown to decrease the oxygen extraction of the gut, specifically of the mucosa, and there is some concern that infusion of dopamine could result in mucosal ischemia (35). Although we did not measure differential transmural flow, our data showed that in the newborn lamb absolute blood flow to the gut and kidney was not compromised at conventionally used rates of dopamine infusion.

Cerebral blood flow increased in our lambs at the 80 and 160 $\mu \mathrm{g} / \mathrm{kg} / \mathrm{min}$ rates of infusion despite the fall in cardiac output. Driving pressure, i.e. aortic pressure, progressively increased with each rate of dopamine infusion. Cerebral blood flow remained constant at the 5 and $20 \mu \mathrm{g} / \mathrm{kg} / \mathrm{min}$ rates of infusion despite an increase in cardiac output and then increased with the increase in aortic pressure at the $80 \mu \mathrm{g} / \mathrm{kg} / \mathrm{min}$ without significant change in cardiac output suggesting that the limits of autoregulation had been exceeded.

Coronary blood flow increased in our lambs at rates of dopamine infusion of 80 and $160 \mu \mathrm{g} / \mathrm{kg} / \mathrm{min}$. In light of previously cited studies, it is unlikely that dopamine had a direct vasodilating effect on the coronary vascular bed at these high rates of infusion $(32,33)$. Presumably the increase in coronary blood flow was the result of an increased oxygen demand by the myocardium. Heart rate and ventricular wall stress as a function of increased ventricular afterload both increased in our lambs. Both of these have been shown to increase myocardial oxygen demand (43). Adenosine, a metabolic product of ATP breakdown that relaxes vascular smooth muscle, appears to be the local mediator for coronary vasodilatation in conditions of increased oxygen consumption (44).

We conclude that dopamine increases cardiac output in newborn lambs, presumably by increasing myocardial contractility. The inotropic reserve in young lambs, however, does appear limited with an inotropic:afterload mismatch evident at high rates of dopamine infusion. Dopamine does not appear to have any specific vasodilating properties in the organ beds tested and, at high rates of infusion, decreases blood flow to the gut and kidneys.

\section{REFERENCES}

1. Driscoll DJ. Gillette PC. McNamara DG 1978 The use of dopamine in children. J Pediatr 92:309-314

2. Feltes TF. Fike CD. Hansen TN 1986 Effects of dopamine and nifedipine infusions on the pulmonary circulation of the lamb. Pediatr Pharmacol 5:261-271

3. Rudolph AM. Hcymann MA 1967 Circulation of the fetus in utero: Method of studying distribution of blood flow, cardiac output and organ blood flow.
Circ Res 21:163-184

4. Makowski EL, Meschia G, Droegemueller W, Battaglia F. 1968 Measuremen of umbilical arterial blood flow to the sheep placenta and fetus in utero. Circ Res 23:623-631

5. Archie JP Jr, Fixler DE, Ullyot DJ, Hoffman JIE, Utley JR, Carlson EL 1973 Measurement of cardiac output with and organ trapping of radioactive microspheres. J Appl Physiol 35:148-154

6. Zar JH 1984 Biostatistical Analysis. Englewood Cliffs, NJ, Prentice-Hall, Inc

7. Lang P, Williams RG, Norwood WI, Casteneda AR 1980 The hemodynamic effects of dopamine in infants after corrective cardiac surgery. J Pediatr 96:630-634

8. Goldberg Ll 1972 Cardiovascular and renal actions of dopamine: potential clinical applications. Pharmacol Rev 24:1-29

9. Scholz H (1984) Inotropic drugs and their mechanisms of action. J Am Coll Cardiol 4:89-97

10. Reuter H. Scholz H 1977 The regulation of calcium conductance of cardiac muscle by adrenaline. J Physiol (Lond) 264:49-62

11. Zaritsky LA, Chernow B 1984 Use of catecholamines in pediatrics. J Pediat 105:341-350

12. Gatgounis J 1965 Structural activity relationships of a series of amines injected before and after monoamine oxidase inhibitor. Arch Int Pharmacodyn Ther $154: 412-420$

13. Goldberg LI, Sjoerdsma A 1959 Effects of several monoamine oxidase inhibitors on the cardiovascular actions of naturally occurring amines in the dog. J Pharmacol Exp Ther 127:212-218

14. Tsai TH, Langer SZ. Trendelenburg U 1967 Effects of dopamine and alphamethyl-dopamine on smooth muscle and on the cardiac pacemaker. J Pharmacol Exp Ther 156:310-324

15. Driscoll DJ, Gillette PC, Ezrailson EG, Schwartz A 1978 Inotropic response of the neonatal canine myocardium to dopamine. Pediatr Res 12:42-45

16. Cheng JB, Goldfien A, Cornett LE, Roberts JM 1981 Identification of betaadrenergic receptors using $[\mathrm{H}]$ dihydroalprenolol in fetal sheep heart: direct evidence of qualitative similarity to the receptors in adult sheep heart. Pediatr Res 15:1083-1087

17. Friedman WF 1972 The intrinsic physiologic properties of the developing heart. Prog Cardiovasc Dis 15:87-111

18. Drummond WH, Webb IB, Purcell KA 1981 Cardiopulmonary response to dopamine in chronically catheterized neonatal lambs. Pediatr Pharmacol 1:347-356

19. Williams BJ. Drummond WH 1983 The effect of alpha-adrenergic blockade on the pulmonary vascular response to dopamine in neonatal lambs. Pediatr Res 17:464-467

20. Vapaavouri EK. Shinebourne EA, Williams RL, Heymann MA, Rudolph AM 1973 Development of cardiovascular response to autonomic blockade in intact fetal and neonatal lambs. Biol Neonate 22:177-188

21. Downing SE. Talner NS, Gardner TH 1965 Ventricular function in the newborn lamb. Am J Physiol 208:931-937

22. Zapata $P$, Zuazo A 1980 Respiratory effects of dopamine-induced inhibition of chemosensory inflow. Respir Physiol 40:79-92

23. Fisher DJ 1986 Acidaemia reduces cardiac output and left ventricular contractility in conscious lambs. J Dev Physiol 8:23-31

24. Hansen TN, Haberkern CM. Hazinski TA, Bland RD 1984 Lung fluid balance in hypoxic lambs. Pediatr Res 18:434-440

25. Hansen TN, Hazinski TA, Bland RD 1984 Effects of asphyxia on lung fluid balance in baby lambs. J Clin Invest 74:370-376

26. Haberkern CM. Bland RD 1981 Effect of hypercapnia on net filtration of fluid in the lungs of awake newborn lambs. J Appl Physiol 51:423-427

27. Fisher DJ, Gross DM 1983 The effect of atrial pacing-induced tachycardia on left ventricular contractile function in conscious newborn and adult sheep. Pediatr Res 17:651-656

28. Grover RF, Wagner Jr WW, McMurtry IF, Reeves JT 1983 Pulmonary circulation. In: Handbook of Physiology, Sect 2, Circulation, Vol 3. Washington, DC, American Physiological Society, pp 103-136

29. McNay JL, McDonald Jr RH, Goldberg LI 1965 Direct renal vasodilatation by dopamine in the dog. Circ Res 16:510-517

30. Von Essen C. Zervas NT, Brown DR, Koltun WA, Pickren KS 1980 Local cerebral blood flow in the dog during intravenous infusion of dopamine. Surg Neurol 13:181-188

31. Toda N 1983 Dopamine vasodilates human cercbral artery, Experientia 39:1131-1132

32. Schuelke DM, Mark AL, Schmid PG, Eckstein JW 1971 Coronary vasodilatation produced by dopamine after adrenergic blockade. J Pharmacol Exp Ther 176:320-327

33. Toda N, Goldberg LI 1975 Effects of dopamine on isolated canine coronary arteries. Cardiovasc Res 9:384-389

34. Ross G, Brown W 1966 Cardiovascular effects of dopamine in the anesthetized cat. Am J Physiol 212:823-828

35. Giraud GD. MacCannell KL 1984 Decreased nutrient blood flow during dopamine- and epinephrine-induced intestinal vasodilation. J Pharmacol Exp Ther 230:214-220

36. Brooks HL, Stein PD, Matson JL, Hyland JW 1969 Dopamine-induced alterations in coronary hemodynamics in dogs. Cir Res 24:699-704

37. Angehrn W, Schmid E. Althaus F, Niedermann K, Rothlin M 1980 Effect of dopamine on hepatosplanchnic blood flow. J Cardiovasc Pharmacol 2:257265

38. Itoh H. Kohli JD, Rajfer SI, Goldberg LI 1985 Comparison of the cardiovas- 
cular actions of dopamine and epinephrine in the dog. J Pharmacol Exp Ther 233:87-93

39. Goldberg LI. Toda N 1975 Dopamine induced relaxation of isolated canine renal. mesenteric, and femoral arteries contracted with prostaglandin $F_{2}$. Circ Res 26-27 (suppl 1):I-97-102

40. Gootman N, Buckley MJ. Gootman PM. Nagelberg JS 1982 Age-related effects of single injections of dopamine on cardiovascular function in developing swine. Dev Pharmacol Ther 4:139-150

41. Gootman N. Buckley MJ. Gootman PM. Griswold PG. Mele FJ. Nudel DB
1983 Maturation-related differences in regional circulatory effects of dopamine infusion in swine. Dev Pharmacol Ther 6:9-22

42. Buckley NM, Brazeau P, Frasier ID 1983 Cardiovascular effects of dopamine in developing swine. Biol Neonate 43:50-60

43. Parmley WW, Tyberg JV 1976 Determinants of myocardial oxygen demand In: Yu PN, Goodwin JF (eds) Progress in Cardiology. Philadelphia, Lea and Feiberger, pp 19-36

44. Wilcken DEL 1983 Local factors controlling coronary circulation. Am J Cardiol 52:8A-14A 